\title{
Marcela Chapetón*
}

\section{Creating reading clubs that foster resiliency: Theoretical foundations}

\author{
Creación de clubes de lectura que fomentan resilencia: \\ Fundamentos teóricos
}

\begin{abstract}
This article presents a discussion on current theoretical trends that consider reading as a literacy social practice and resiliency as a building process. The concepts explored in this paper are central part of the theoretical and research based foundations of a literacy proposal conducted to identify resiliency building processes through dialogic experiences generated after reading events. The core concepts to be discussed in this article constitute the basis for the creation of a reading club viewed as an alternative to contribute to the education of individuals as social, resilient readers. Reading in this proposal is understood as a situated social literacy practice in which reading transactions and readers' response, critical pedagogy, and processes of resiliency building play a central role in the development of the reading club.
\end{abstract}

Keywords. Reading club, reading as a situated social practice, reading transactions, resiliency building and critical pedagogy.

Resumen. Este artículo presenta los principios teóricos más recientes que consideran la lectura como una práctica social alfabetizadora, y la resiliencia como un proceso de construcción. Los conceptos explorados en este documento son parte central de los fundamentos teóricos que orientan una propuesta alfabetizadora desarrollada para identificar procesos de resiliencia a través de experiencias dialógicas generadas en encuentros de lectura. Así, los conceptos por discutir en este documento constituyen la base para la creación de un club de lectura visto como un programa alternativo que contribuye a la educación de individuos como lectores sociales resilientes. La lectura en esta propuesta se asume como una práctica social situada alfabetizadora, donde la transacción y respuesta a la lectura, la pedagogía crítica y los procesos de construcción de resiliencia son centrales en el desarrollo del club.

Palabras clave. Club de lectura, la lectura como una práctica social situada, transacción y respuesta a la lectura, construcción de resiliencia y pedagogía crítica.

\section{Introduction}

Though many interpretations and definitions have been given to reading, and authors have, from different perspectives, worked on this vast area of
* Marcela Chapetón is a full-time teacher at Universidad Pedagógica Nacional. She holds an M.A in Applied Linguistics to the Teaching of English as a Foreign Language from Universidad Distrital Francisco José de Caldas. Her research interests are literacy, language teaching methodology and teacher training.E-mail: cchapeton@uni.pedagogica.edu.co 
language, it is certain that reading plays an essential role in the daily life of individuals. Reading goes, as I understand it, far beyond decoding sound/symbol correspondences, it implies not only linguistic knowledge but a set of social processes which bring into play the crucial role of literacy.

I consider that developing alternative reading programs can contribute a lot to the education of individuals as social readers in three main ways: First, the role that reading might play in the personal and social development of a self. Second, as meaning is socially constructed, I consider dialog and discussion issues of high value within a community which shares similar background and socio-cultural characteristics. Third, the relevance of creating spaces for self and free expression where people are sharing ideas, opinions, emotions or whatever emerges from the transactional interaction between readers and texts.

Thereby, the main purpose of this document is to share with the reader the theoretical framework that guides a qualitative research project whose objective is to document, observe and analyze the responses given by participants when enrolled in reading club sessions. The reading club sessions are proposed as alternative programs to foster resilient environments in education in order to make the reading event a significant experience in which participants have the opportunity to communicate, express, negotiate and share critical responses to reading at dialogical basis.

The trends discussed in this paper view reading as a situated social literacy practice and language as a transformative agency. Also, the transactions that take place during the reading event and the kind of readers' responses at the reading club are addressed. Finally, there is an account of the way critical pedagogy shapes the development of the reading club and its relation to building resiliency processes.

\section{Literacy: Sociocultural, transactional and critical perspectives}

Literacy is one of the constructs that illuminate my interest in creating a reading club as an alternative to contribute to the education of individuals as social readers. Authors like Freire argue that literacy is a political project in which men and women assert their right and responsibility not only to read, understand and transform their own experiences, but also to reconstitute their relationship with the wider society. Literacy for Freire and Macedo (1987a) is part of the process of being self-critical about the historically constructed nature of one's experience by giving meaning and expression to their own needs and voices as part of a project of self and social empowerment. From my experience in the development of the reading club, to be able to name a personal experience is part of what Freire meant as "to read the world" and it constitutes the starting point to understand the social nature of the realities that surround us.

Freire (1991) explains that reading does not consist merely of decoding the written world of language; rather it is preceded by and interlaced with knowledge of the world, thus, language and reality are dynamically interconnected. Freire and Shor (1987b) highlight the importance of the need to learn, as teachers, what it really means to read: "I say that reading is not just to walk on the words, and it is not flying over the words either. Reading is re-writing what we are reading " (p. 10). Reading for Freire is to discover the connections between the text and the context of the text, and also how to connect the text/context with the personal and social context of the reader. He explains that criticism creates an intellectual discipline which involves asking questions to the reading, to the writing, to the book, to the text. He rejects being submissive to the text, instead he invites the reader to fight with the text, to engage in a conflict with the text, in spite of loving it. 
A text in the reading club goes far beyond the printed word. A text is everything possible to be read and to be re-written. Our own realities and life experiences are texts we can read aloud and re-write by being critical readers of them.

Miall \& Kuiken (1994), suggest that research in the field of literacy practices may inform about how language of literature fosters changes in the way we understand our personal life-worlds. I consider that being resistant readers, having the chance to communicate, express, negotiate and share critical responses to reading, is a way to understand our worlds and it is a way to foster changes and be reflective of our lives by creating a social-supportive network among the participants of that community of readers.

As Freire (1987; 1991), Baynham (1995) and Gee (2003) reject the traditional view of literacy -the ability to read and write; coding and decoding printed texts- and replace it with a socially and culturally situated perspective. Literacy has developed to serve social purposes in creating and exchanging meaning, and according to Baynham (1995), it is best understood in the context of use. He asserts that literacy as practice involves researching literacy as "concrete human activity" (p. 2) since it provides a way of linking the cognitive and linguistic dimensions with the social, opening up the possibility of an integrated approach to the study of literacy in use.

Gee (2003), points out that sociocultural approaches to language and literacy, view literacy within its sociocultural contexts and treats it as a social cognitive skill that has to do with human relationships. The author highlights the connections literacy has to issues such as power, social identity and to ideologies. Both, Baynham (1995) and Gee (2003) assert that literacy practices shape and are shaped by social factors, by social contexts.

To sum up, literacy in this proposal is understood as a social practice, a purposeful activity that takes place in social interactions among participants. It is focused on reading as a social literacy practice, situated within a community of readers who share critical responses to reading. Thus, the following section of this paper presents a discussion of what reading as a situated social practice implies and how it contributes to the development of the reading club sessions.

\section{Reading as a situated social practice}

According to Baynham (1995), for the last twenty years the most influential approach to reading has been the psycholinguistic model of reading, developed by Ken and Yetta Goodman, and Frank Smith. This approach emphasizes the interaction of readers with texts, reading for meaning, reading as a "psycholinguistic guessing game". Thus, the reader uses the "world in the head " which includes world knowledge of the kind referred by Freire "knowing the world precedes knowing the word", along with knowledge of linguistic organization for prediction in reading a text. For these theorists comprehension depends upon prediction (Smith, 1997).

Goodman (1996) claims that reading is a constructive process in which two readers will never produce equal meaning for a given text and no reader's meaning will ever completely agree with the writer's meaning. He also states that texts go beyond simply collections of letters and words and argues that making sense of texts involves issues such as complex control, by both readers and writers, of how language works and how texts are constructed. He affirms that the sense one can make of a text depends on the sense one brings to it. Smith, (1997) agrees by saying that what one already has in his/her head is the only basis for making sense of the world and learning more about it.

The value of this psycholinguistic approach, as Baynham (1995) explains, relies on the emphasis made on what readers do, on how they read and the close observation of practice as a means of 
theory building. However, Baynham argues that its limitation is that it stays within the psycholinguistic sphere of readers interacting with text, and does not bring into play the "contextually determined factors of literacy practice in general” (p. 172).
Table 1 portraits my understanding of the main aspects that built the psycholinguistic approach in contrast with those that are central for the pragmatic theory of reading as a situated social practice (RSSP) proposed by Baynham.

Table 1. Psycholinguistic Approach and the Pragmatic Theory of Reading as a Situated Social Practice (RSSP)

\begin{tabular}{|c|c|}
\hline Psycholinguistic model & Pragmatic theory (RSSP) \\
\hline $\begin{array}{l}\text { - Natural language development. } \\
\text { - Too specific social practices and contexts. }\end{array}$ & $\begin{array}{l}\text { - Language development is socially constructed in } \\
\text { interaction in specific social practices and contexts. }\end{array}$ \\
\hline $\begin{array}{l}\text { - Reading for meaning approach. Pedagogical practices: } \\
\text { learner- centered, learners readers, shared meaning and } \\
\text { access, different interpretations of the same text. }\end{array}$ & $\begin{array}{l}\text { - Different interpretations/readings of the same text. } \\
\text { - Differential access to the meanings. } \\
\text { - Different reading practices. }\end{array}$ \\
\hline - Discourse organization. Whole text. & $\begin{array}{l}\text { Distinguishes different kinds of texts. Different internal } \\
\text { organization. Micro-structure of texts. } \\
\text { - Different purposes of reading. }\end{array}$ \\
\hline $\begin{array}{l}\text { - Systematic relationships between text and context: } \\
\text { prediction very local making meaning of what the text } \\
\text { presupposes locally. }\end{array}$ & $\begin{array}{l}\text { Draws in the higher order of socio-cultural dimensions. } \\
\text { Considers ideological perspectives. The dimension of } \\
\text { practice. }\end{array}$ \\
\hline - Context of situation. & - Context of culture. \\
\hline - What reading $I S$. & - What reading DOES. \\
\hline $\begin{array}{l}\text { - Phonemic awareness. } \\
\text { - Miscue Analysis. } \\
\text { - "Reading goes on behind the eyes". } \\
\text { - "The world in the head". } \\
\text { - "Ideal Reader": active, risk taker, able to predict. } \\
\text { - Natural language learning. } \\
\text { - Reading for meaning. }\end{array}$ & $\begin{array}{l}\text { - Brings in spoken language. } \\
\text { - Brings the text readings of the world. } \\
\text { - Involves consulting the perceptions of the } \\
\text { participants. } \\
\text { - Emphasizes reading as both social process and social } \\
\text { practice. } \\
\text { - Critical reading: asking questions on the what, why, } \\
\text { how. } \\
\text { - It implies both acceptance and rejection. }\end{array}$ \\
\hline
\end{tabular}

Baynham affirms that the drawbacks of the psycholinguistic approach are first, that it tends to focus on one kind of reading and second, it constructs an idealized reader who may be quite culture-specific which means that he is constructed through cultural and ideological presuppositions. In his words: "...it fails to include the level of textual organization in its model, thus ignoring the variety and diversity of text types" (p. 173).
In contrast, Baynham (1995) proposes a new approach to reading which is a linguistic-pragmatic account of reading as it emphasizes first the dimension of text organization and second the social processes involved in text construction and interpretation, considering the interaction of linguistic knowledge, with interpretative work and background knowledge schemata. It encompasses the dimension of text as social practice and 
therefore views reading as social practice that brings into play the crucial role of critical reading. Figure 1 shows my interpretation of the interrelated components of the pragmatic theory proposed by Baynham, which considers reading as a situated social practice.

Figure 1. Reading as a situated social practice.

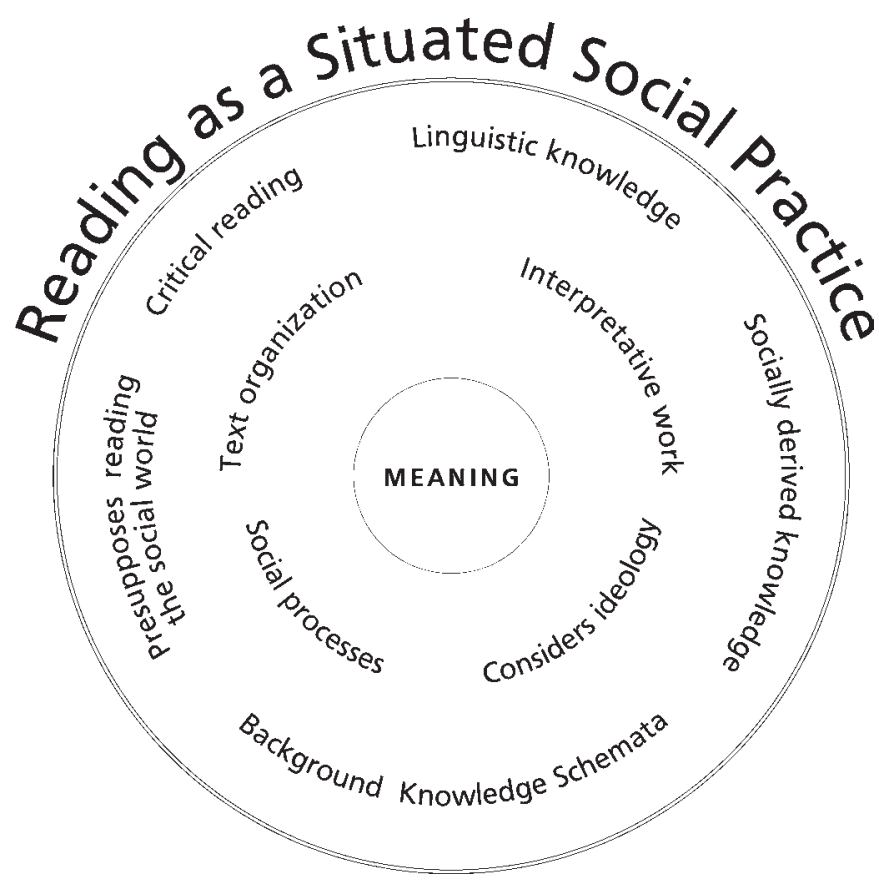

Reading as a situated social practice is summarized by Baynham, as follows:

Reading is situated because of its dependence on the interaction of linguistic knowledge, background knowledge and interpretative work.

Reading is social because, even in the stereotypical case of solitary reader engaging with text, the activity of reading routinely implicates the social-indeed reading strictly can't take place without the implication of socially derived knowledge.

Reading is social practice because the activity of reading presupposes reading the social world and introduces the potential for critical, resistant readings, not simply accommodations to the givens of text (1995: 207).

My interest in this pragmatic theory of reading relies on its assertion that reading is a process of interaction of different dimensions of text organization and social processes which are involved in text construction and interpretation. Involving linguistic knowledge with interpretative work and background knowledge which includes ideology, perspectives and even roles within the society, it introduces the possibility for critical, resistant readings. I consider that this view of reading as a situated social practice widens the scope and goes beyond traditional practices as it acknowledges the personal and social perspectives of reading.

McManus (1998), has a common point with Baynham when she states that readers belong to same "interpretive communities" with shared reading strategies, values and interpretive assumptions (i.e., shared "discourse”). She also argues that readers are situated in a common cultural/ historical setting and shaped by dominant discourses and ideologies. Rosenblatt and Karolides (1999) insist on reading as a unique event in time, as there 
is always a particular moment in the personal life of the reader as well as a particular social and cultural environment. She also acknowledges the different possible interpretations risen out of a text, as readers bring different knowledge and assumptions and different social and historical contexts.

These new dimensions of reading related to the social, cultural and ideological situations of readers are particularly relevant to this reading club proposal as participants might evidence such dimensions in their position in the world and through their discourse. A discussion on the reading transactions that take place during the reading club sessions and the nature of the responses to reading is presented as follows.

\section{Reading transactions in the reading club}

"A poem is what the reader lives through under the guidance of a text"

Louise Rosenblatt

With the publication of Literature as Exploration, Rosenblatt rejected the idea that the text is a static container of meanings and argued that meanings instead arise from the transaction of readers and texts in particular contexts. She explains that reading transactions required recognition of a personal, social and cultural matrix. She uses the term transaction to emphasize that the meaning is being built up "through the back-and-forth relationship between reader and text during a reading event" (1991: 162). The author asserts that transaction applies to individuals' relations to one another, whether in the family, the classroom, the school or in the broader society and culture. Borasi et al. (1998), in their exploratory research study pointed out that Rosenblatt chose the term transaction to call attention to the way in which the reader and the text shape and are shaped by each other during the reading event.
As Baynham (1995), and Freire (1987a, 1987b, 1991), Rosenblatt states that reading is a relationship between a human being and the text, and the purpose of that activity involves the whole person. "Reading is for the knowledge, the experience, and the wisdom that the printed word makes possible for us, giving us communication with other minds across time and space, enabling us to share their thoughts and their worlds" (1991: 115). She argues that the reader brings to the text the "internalized sum", the accumulation or memory of all psychological events, past organismic encounters with language and the world.

In the reading transaction for instance, the words of the text may activate elements from referents of memory. She clarifies, that this includes not only those public referents or objects to what the verbal symbols point, but also the personal referents: sensuous, affective, imaginal, and associative which, in words of Rosenblatt (1991), encompass not only ideas but, sensations, images, precepts and concepts, states or qualities of states, and feelings. Thus, the author explains the evocation of meaning from the text in which the personal referents intervene as follows:

The evocation of meaning from the text requires a selecting-out from the reservoir of thought and feeling, the acceptance of some elements into the center of attention, and the relegation of others to the periphery of awareness (Rosenblatt, 1991: 118).

According to Rosenblatt (1985), the transactional theory resists the formalist tendency to concentrate on the text as all important and the reader as passive, and also avoids the alternative extremism of some subjective literary theorists who view the reader as all important and the text as passive or secondary. She claims that reader and text are mutually essential to the transaction and that meaning happens during the transaction between the reader and the text. "As soon as we start to say what a text means, we are reporting and analyzing the transaction we have just engaged in. We return to 
the text to see how, drawing on a personal reservoir to transact with the text, we arrived at our particular interpretation" (1999: 164).

Transactional Reading Club sessions can take place at schools, universities, libraries or at any other kind of institution where people can get together to share a mutual reading of the world and the word. A careful selection of short stories and short tales might be done in advance (See suggested readings in the literature references). After the community has been brought together, one or more different books can be read aloud each session. At the beginning of each meeting, one person can read aloud for the participants who are invited to choose what to read first by reading the titles and exploring the covers of the books. As space for dialogue and interaction is open, participants are free to make comments and predictions, ask questions, share life experiences, feelings or any kind of aesthetic responses. Even though there is not a formal guide with prompts after the reading aloud, the conversations might be enriched by asking two main questions open enough to trigger discussion: How did you like the story? And, Are there any connections with your life experiences? Being so, transactions among readers and texts are fostered. The results of those transactions may generate a resilient environment in which dialogue, reflection, networking and social support is offered.

I consider Rosenblatt's transactional theory of reading very illuminating for the development of this reading club proposal as its main purpose is to share life experiences, feelings, thoughts, and everything the reader wants to express when making meaning of their worlds and those of the text by being enrolled in dialogic transactions.

Research on reading has included a variety of issues such as children's stories reading (Belton, 2000); sense-making and reading difficulty (Thomas and Davies, 1997); reading transactions with math texts (Borasi et al., 1998) among others. However, research on the dialogic transactions that take place through reading as a situated social practice among participants of a reading club has not been found in my search so far.

\section{Readers' response: The "aesthetic” stance towards the text}

There are three traditions of thought about readers' responses to literature: the political, the critical and the empirical traditions. These traditions enlighten this proposal as the participants are part of a particular discourse community that respond to the text when enrolled in the reading club. I consider relevant to briefly review the main issues of each one of these traditions, in order to make the necessary distinctions among them as they have helped shape the others. However, the tradition which this proposal mainly relies on is the critical as it deals with the importance of transactions and the role of critical literacy which enables the reader to understand the world around her/him and transform it by being a resistant reader of the world.

According to Marshall (2000), who presents a full review of research on response to literature, there are three traditions that differ from each other not only because they engage in distinct questions about response, but also because they address different audiences and point toward different bodies of intertextual reference for their evidence and authority.

Firstly, the political tradition, as Marshall (2000) explains, concerns primarily with the moral dimensions of reading literature for individuals and communities, and thus by extension examines the relationships between literature and the political, religious, or cultural well-being of those who read it. Work in this tradition tends to be conducted by public intellectuals working in public forums and finds its origins in Plato's Republic. In this tradition, poetry and great literature are considered as "a force powerful enough to heal the moral and spiritual decay" (p. 383). 
Secondly, work on the empirical tradition has been conducted by researchers whose interests are more closely associated with teachers, students and schools (Marshall, 2000). Theorists in this tradition have categorized responses in a variety of ways, locating the source of variation either in the literary text being read, the reader doing the reading or the context in which the reading is taking place.

Finally, the critical tradition of thought about literary response is called specifically readerresponse theory. Marshall states that most reviews locate the beginnings of contemporary response theory in the work of Richards (1929) and Louise Rosenblatt (1938).

According to Marshall (2000), Richards' contributions were more empirical. He asked his students to respond freely to poetry and categorized their responses by their reliance on sentimentality, doctrinal adhesions, or stock responses among others. Marshall strongly criticizes the fact that Rosenblatt's early contributions to reader response theory have been widely ignored by most of those working in the critical tradition. He argues that it was only from the early 1970 s to the early 1980 s that the reader response theory was most widely discussed and fully developed. The later work of Fish in the 1980s, as discussed by the author, locates a powerful source of readers' responses in the sociocultural context in which they are reading. Individual responses are shaped by social and cultural assumptions given in historically specific cultural situations.

Marshall in his review criticizes the fact that the critical tradition has generated very little data about how individual readers construct responses to literature. Literature as Exploration, 1938 (Spanish Edition, 2002) is often credited with being the first formulation of readers-response criticism or theory (Rosenblatt, 1985: 103). Rosenblatt constructed her theory on the efferent -public- and the aesthetic private- responses to reading-sense and meaning making.
She claims that there are two ways of reading and responding to reading: First, a nonliterary kind of reading the "efferent" approach or stance in the selective process, in which the readers pay some attention to the sound and rhythm, but the predominant interest is in acquiring information that is wished to retain after the reading has ended. In efferent reading, she argues, a greater proportion of attention is centered in the public, generally shared meanings, and less on the privately felt aspects. This is the kind of meaning the scientist searches: impersonal, repeatable, and verifiable (Rosenblatt, 1991; 1999).

Second, and most appropriate to this reading club proposal, the reader may adopt an "aesthetic" stance towards the text by reading it with attention, of course, to what the words refer to, but mainly to what we are experiencing, thinking and feeling during the reading. For such aesthetic readings, instead of attention mainly to facts and ideas abstracted for specific use afterwards, the reader would focus on what was being lived through during the reading event, on the ideas as they are embodied in the images, the sensations, the emotions, the feelings, and the changing moods (Rosenblatt, 1991; 1999).

I find this differentiation of the types of response to reading crucial, as in the Reading Club our purpose as readers is not to find information in the text (efferent response) but, to respond critically by making living connections engaged in dialogic transactions. Thus, the implementation of the reading club sessions is focused on the aesthetic stance, when the reader transacts aesthetically with the text and shapes it by reacting and responding through her/his emotions, sensations, images, tensions and current lived ideas and experiences.

Miall (1998), states that reading literature may play an important part in developing the self of the reader: more particularly, it provides a context in which the reader's own experience can be reassessed through constructive reformulation of the 
meaning and scope of the emotions. He also argues that responding to literature can be understood as a part of the adaptive system which humans have developed to sustain themselves. Besides, Miall \& Kuiken (1994), suggest that studying literary response offers the opportunity to explore the functions and processes of feeling, with a richness and complexity, and with an ecological validity, that is perhaps unavailable elsewhere. They argue that "research in this field may cast light not only on readers' responses to literary style, but also on the little understood means by which the distinctive language of literature fosters changes in the way we understand our personal life-worlds" (p. 345). In this approach to reader-response, the primary focus falls on the reader and the process of reading rather than on the author or the literary style of the text. Thus, I see this kind of readers' response approach along with the aesthetic response proposed by Rosenblatt as the basis that shape the nature of the reading club sessions of this proposal.

After having presented some of the current and most popular approaches about literacy, reading as a situated social practice, reading transactions and readers' responses from the perspectives of different authors, I discuss how critical pedagogy and resiliency are central issues in the creation of reading clubs as alternative programs.

\section{Critical pedagogy in the reading club}

Critical pedagogy is grounded in the legacy of educators such as Dewey and Vygotsky who near the beginning of the $20^{\text {th }}$ century talked about the traditional versus the progressive education, the nature of freedom and the relevance of considering the students own experiences as a means and goal of education. Vygotsky's legacy includes the relevance of sociocultural learning, the zone of proximal development or our interaction with friends, and the relationship between thought and language, or words and ideas.
However, as Wink (2000) states, much of the critical pedagogy today stands on the shoulders of Paulo Freire. The Freirean transformative pedagogy is a liberating, humanitarian and democratic approach to education that aims at fostering changes in society, valuing students' life experiences and realities. Issues such as critical dialogue, critical reflection and connection to the reality, and the mutual creation and re-creation of knowledge are at the heart of this approach to education which grows in opposition to the banking, traditional education.

According to Paulo Freire and Ira Shor (1987b), liberating education is a critical perspective on education and society, learning for social transformation through critical dialogue about a text or a moment in society, to reveal it, unveil it, in other words, illuminate reality. Freire argues that liberation is not a gift, not a self-achievement, but a mutual process. In the organization and implementation of the reading club sessions, critical dialogue around social issues and experiences lived by participants are at the core in order to name and illuminate crucial issues that are part of their lives. It is accomplished through processes of collective thought at a dialogic basis, where participants in the reading club sessions are problem solvers able to rethink their experiences in the light of transforming social realities.

Several issues are central to this critical theory, which in fact, is a living matter in schools' practice and education. McLaren (2003), states that a major task of critical pedagogy has been "to disclose and challenge the role that schools play in our political and cultural life" (p. 186). He remarks that schools are not only instructional sites, but also cultural arenas where the different ideological and social forms often collide in a constant struggle for dominance. McLaren (2003) explains that the critical perspective allows us to scrutinize schooling more insistently in terms of race, class, power and gender. 
The author presents a look at the major concepts of critical pedagogy, including a deep explanation of each and presenting his journalistic documentation of his own experiences as an inner-city teacher. In his critical overview, he addresses the following concepts as central in critical pedagogy: the social construction of knowledge which as he explains, involves interrelated issues such as class, culture, ideology, and prejudice; the power/ knowledge relation which has to do with discourse, the curriculum, and the curriculum as a form of cultural politics. Still, McLaren (2003) clarifies that there are many more issues to be raised but his review of those concepts is a starting point to help unravel some of the implications that critical pedagogy has to offer for rethinking schooling in the light of transforming society. He points out that critical theorists are united in their objectives: "to empower the powerless and transform existing social inequalities and injustices” (p. 186).

Similarly, Nieto (2002) highlights the numerous connections of issues such as language, literacy and culture, and the need of all teachers becoming knowledgeable in how they affect students' schooling. She argues that issues such as equity and social justice are at the core of education. In agreement with Freire, she also states that education is a political undertaking.

Nieto (2002) presents the tenets of sociocultural theory which include such issues as discourse, hegemony, power, social practice, identity and literacy. She argues that sociocultural and sociopolitical perspectives are first and foremost based on the social relationships and political realities which are at the heart of teaching and learning. She points out that learning emerges from the social, cultural and political spaces in which it takes place, and through the interactions and relationships that occur between learners and teachers. So that, rejecting the common view of learning as transmission of knowledge, she proposes five interrelated, deeply connected and even overlapping concepts that undergird sociocultural and sociopolitical perspectives of education. Those concepts are agency, experience, context, identity and community. Agency or co-constructed learning is a mutual discovery by students and teachers, the ability to construct meaningful and important knowledge where all students have the ability to think, reason, and reflect. Regarding experience, the author rejects the fact that the experience of young people of culturally and linguistically diverse backgrounds who have not had the kinds of experiences of the mainstream, are not valued as effective for academic success or just ignored. She explains that cultural capital is evident in such intangibles as values, tastes, and behaviors and through cultural identities such as language, dialect and ethnicity. She argues that individuals form these diverse communities are placed at a disadvantage simply due to their experiences and identities, which leads to the need of understanding those "power relations as fundamental issues of the real school life" (Nieto, 2002: 8).

She also highlights the need to consider the impact of teachers' attitudes concerning the cultural capital that their students do bring to school, and their roles in affirming or ignoring those sociocultural backgrounds and experiences. As the author argues, "learning and achievement are not merely cognitive processes, but complex issues that need to be understood in the development of community" (Nieto, 2002: 18).

It is relevant to consider at this point, Corporación Región (2003), as an example of educational programs in Colombia that have had the major concepts of critical pedagogy at the core. In Medellín, for instance, due to the social realities that the community has been experiencing since the 1980 s, educational institutions were challenged to shape their pedagogical actions as they were shaped by issues such street violence, drug dealing, drug consumption and forced internal displacement. In the book Una escuela con-sentido (A school withsense), Corporación Región (2003) provides a descriptive account of the methodological proposals 
which have been implemented as a response to the existing critical conditions. Their proposal consists of three main strategic modules which are: $\mathrm{La}$ escuela elegante (The elegant school); Ambientes escolares preventivos (Preventive schooling environments); and Cualificación de los gobiernos escolares (Qualification of school governments). Corporación Región (2003) argues that this kind of school, aims at strengthening and qualifying the educational institutions in Medellín, by fostering an education in and for the social realities; active participation of students and teachers in the construction and research of daily life issues and concerns, involving their own experiences and establishing a wider relation with their surroundings. A school environment where there is respect, trustiness, equality, no discrimination and a better communicative relation among the community members.

As I see it, this critical trend in education permeates this Reading Club proposal as it is based on principles that value the students' realities, experiences and voices. In the reading club sessions there is critical reflection and dialogue that aim at creating a supportive, resilient environment where social networking and resilience factors are fostered among participants.

I will turn now to the definition of resiliency and its relevance for the development of this proposal. I will pay close attention to the protective and resilience factors that different authors have identified as crucial in the building resiliency process.

\section{Resiliency as a building process}

According to Henderson and Milstein (1996), resiliency is a dramatic new perspective which has emerged from the fields of psychiatry, psychology, and sociology, on how children and adults bounce back from stress, trauma and risk in their lives. The authors argue that the idea of resiliency also refers to the fact that people can bounce back from negative life experiences and often become even stronger in the process of overcoming them. Research on this field has shown that "with an adequate resiliency-supporting environment, strength can emerge from adversity” (p. 3).

The authors claim that an understanding of how adults exposed to both personal and work-related stress bounce back is just emerging. Henderson and Milstein (1996), explain that when an individual of any age experiences adversity, he or she also -ideally- experiences individual and environmental characteristics, protective factors, that buffer that adversity; the availability of those protective factors determine the type of adaptation to the new situation and how the individual adapts to adversity.

Theory and research about resiliency as a process have shown that there are several factors that have an impact on the resilience or vulnerability of the person who faces adversity. According to Kotliarenco (1997), a protective factor is a trait, situation, circumstance, skill or characteristic that acts as a means for the individual to be resilient. It increases resiliency and decreases vulnerability. A risk factor is a situation or circumstance that decreases the person's ability to be resilient and increases vulnerability. The presence or lack of protective and risk factors may affect whether positively or negatively social and emotional development, academic achievement, physical and mental health.

Resiliency, as Henderson and Milstein (1996) state, is a characteristic that varies from person to person and can grow or decline over time; protective factors are characteristics within the person or within the environment that mitigate the negative impact or stressful situations and conditions. Grotberg (2002) states that everyone faces adversity and no one is exempt, but whether such experiences crush or strengthen an individual depends on the resiliency factors around.

Grotberg (2002) asserts that resilient behaviors require resiliency factors and actions. She points 
that dialogue is action and interaction that fosters the identification of resiliency factors. I consider that the reading club sessions are actions that serve as opportunities to explore and promote resiliency features through dialogic interactions among the participants. The purpose is to provide them with a resilient environment in the reading club sessions, in which adversities are named, shared and discussed.

Resiliency factors have been grouped by Grotberg as: internal strength - "I AM"-, abilities - "I CAN"-, and social support - "I HAVE”-. The author explains that a resilient person is able to talk about those things that are scary or troublesome, is able to look for the appropriate moment to talk about them and someone to listen, and search for solution/actions. In her research, she has identified that a resilient person does not need all of these features to be resilient, but having only one is not enough, resilience, she argues, results from a combination of these features used by individuals and drawn from the three sources grouped by Grotberg as the "I am, I can and I have" factors:

An individual may be loved (I HAVE), but if $\mathrm{s} / \mathrm{he}$ has no inner strength (I AM) or social interpersonal skills (I CAN), there can be no resilience. An individual may have a great deal of self-esteem (I AM), but if s/he does not know how to communicate with others or solve problems (I CAN), and has no one to help him or her (I HAVE), the person is not resilient (Grotberg, 1995: 10).

Seven internal characteristics called "resiliencies" have been proposed by The Wolins (1993) as cited by Henderson and Milstein (1996) from their research studies on various levels of stressful situations with children and adults. These resiliencies are: Initiative or the individual's ability to take action. Independence, when the adult behaves with autonomy. Insight or the developed perception of what is wrong and why. Relationship that is the complex set of abilities that enable the individual to connect with others. Morality which means altruism and acting with integrity. Humor and creativity.

However, resiliency theorists as Infante (2002), who presents a literature review on resiliency, and researchers (Manciaux, 2002; Melillo, 2002) clarify that resiliency is a process more than a list of features or characteristics found whether in the individual or the environment and building resiliency relies on the environmental support structures to which a person is exposed. That is the reason for the growing interest in providing environments and conditions that foster individual and community resilience or protective factors. These conclusions were discussed and presented as part of a symposium held around resiliency research projects conducted by French students and researchers (Manciaux, 2002) in Cali, Colombia.

As mentioned earlier, dialogue is considered an action that fosters resiliency both, in individuals and communities. The reading club sessions aim at providing a supportive resilient environment where dialogue and interaction are generated during the reading event. It provides participants with a space where they can feel free to explore and share emotions, concerns, feelings and thoughts by being critical readers of the word and the world that surround them.

\section{Final comments}

In short, the nature of the reading club proposed here, is based on current trends that see reading as a situated social practice and resiliency as a building process. Having in mind pragmatic considerations towards reading, reading transactions, an aesthetic response to reading and a liberatory, critical perspective on pedagogy, this reading club proposal offers a multidisciplinary opportunity to create spaces for reflection, community support, networking and freedom. Such an environment may foster resiliency building processes among participants willing to interact, share, reflect and grow together when enrolled in reading club sessions. 


\section{References}

BAYNHAM, M. (1995). Literacy Practices: Investigating Literacy in Social Contexts. London and New York: Longman. BELTON, T. (2000). "Reading beneath the lines of children's stories". Educational Research, 42 (3), pp. 251-260.

BORASI, R. et al. (1998). "Using transactional reading strategies to support sense-making and discussion in mathematics classrooms: an exploratory study”. Journal for Research in Mathematics Education, 29 (3), pp. 275-305.

CHAPETÓN, M. (2004). Fostering Resiliency: A Way to Share Literate Voices beyond the Classroom Bounds. Master Thesis (unpublished). Universidad Distrital Francisco José de Caldas. Bogotá.

CORPORACIÓN REGIÓN. (2003). Una escuela con-sentido. Medellín: Corporación Región.

FREIRE, P. (2002). Pedagogy of the Oppressed. $30^{\text {th }}$ anniversary edition. New York: Continuum.

(1991). "The importance of the act of reading”. In: B. Miller, R. Hubbard. (ed.), Literacy in Process. New York: The Heinemann Reader. pp. 21-26

\& MACEDO, D. (1987a). Literacy: Reading the Word \& Reading the World. London: Bergin \& Garvey.

\& SHOR, I. (1987b). A Pedagogy for Liberation: Dialogues on Transforming Education. Westport: Bergin \& Garvey.

GEE, J. (2003). Social Linguistics and Literacies: Ideologies in Discourses. London: Routledge Falmer.

GOODMAN, K. (1996). On Reading. Canada: Scholastic Publications.

GROTBERG, E. (2002). "Nuevas tendencias en resiliencia”. En: Melillo, A. Resiliencia: Descubriendo las propias fortalezas. Buenos Aires: Paidós.

(1995). The International Resilience Project. A Guide to promoting Resilience in Children: Strengthening the Human Spirit. Practice and Reflection series, Bernand Van Leer Foundation.

HENDERSON, N.; MILSTEIN, M. (1996). Resiliency in Schools. California: Corwin Press.

INFANTE, F. (2002). "La resiliencia como proceso: una revisión de la literatura reciente”. En: Melillo, A. Resiliencia: descubriendo las propias fortalezas. Buenos Aires: Paidós.

KOTLIARENCO, M. A. (1997). Estado del arte en resiliencia. Organización Mundial de la Salud, Fundación Kellog y Ceanim.

MANCIAUX, M. (2002). “La resiliencia: factores de riesgo y vulnerabilidad, factores de protección”. En: Cyrulnik, B. et al. La resiliencia: desvictimizar la víctima. Cali, Colombia: Editorial Rafue.

MARSHALL, J. (2000). “Research on Response to Literature”. In: Kamil, M. et al. (ed.), Handbook of Reading Research. Vol. 3. London: Lawrence Erlbaum Associates Publishers.

McLAREN, P. (2003). Life in Schools: An introduction of critical pedagogy in the foundations of education. Boston: Allyn and Bacon.

McMANUS, B. F. (1998). "Reader Response Criticism - brief synopsis of the critical theory”. En Readings and Assignments. [On line]. http://www.cnr.edu/home/bmcmanus/readercrit.html

MELILLO, A. (2002). Resiliencia: descubriendo las propias fortalezas. Buenos Aires: Paidós.

MIALL, D.S. (1998). “Empowering The Reader Literary Response And Classroom Learning”. In: Roger J. Kreuz and Susan M. MacNealy, (eds.), Empirical Approaches to Literature and Aesthetics. Department of English, University of Alberta: Ablex Publishing Corporation. [On line]. pp. 463-478

\& KUIKEN, D. (1994). "Beyond Text Theory: Understanding Literary Response". Discourse Processes, 17. University of Alberta: Ablex Publishing Corporation, pp. 337-352.

NIETO, S. (2002). Language, culture and teaching: Critical perspectives for a new century. New Jersey: Lawrence Erlbaum Associates.

RICHARDS, I.A. (1929). Practical criticism: A study of literary judgement.. New York: Harcourt. 
ROSENBLATT, L. (2002). Literatura como exploración. México: Fondo de Cultura Económica.

(1991). “Literature-S.O.S.!”. Language Arts, 68 (3), pp. 444-448.

(1991). “The Reading Transaction: What For?". In: Miller \& Hubbard (ed.), Literacy in Process: The Heinemann Reader. New York: Heinemann.

(1985). "Viewpoints: Transaction versus interaction a terminological rescue operation". Research in the Teaching of English, 19 (1), pp. 96-107.

(1938). Literature as exploration. New York: Appleton-Century.

\& KAROLIDES, N. (1999). "Theory and Practice: An Interview with Louise M. Rosenblatt". Language Arts, 77 (2), pp. 158-170.

SMITH, F. (1997). Reading without nonsense. New York: Teachers College Press.

THOMAS, G.; DAVIES, P. (1997). "Special needs: objective reality or personal construction? Judging reading difficulty after the Code of Practice". Educational Research, 39 (3), pp. 263-270.

WINK, J. (2000). Critical Pedagogy. Notes from the Real World. New York: Addison Wesley-Longman.

\section{Literature references}

ANÓNIMO. (1978). El Cocuyo y la mora. Cuento de la tribu Pemón. Colección Narraciones indígenas. Caracas: Ediciones Ekaré. . (1979). El rabipelado burlado. Colección Narraciones indígenas. Caracas: Ediciones Ekaré. . (1999). La capa del morrocoy. Colección Narraciones indígenas. Caracas: Ediciones Ekaré.

ARAÚJO, O. (1988). Miguel Vicente pata caliente. Colección Así vivimos. Caracas: Ediciones Ekaré.

ARMELLADA, C. (1985). El tigre y el cangrejo. Colección Narraciones indígenas. Caracas: Ediciones Ekaré.

BANYAI, I. (2001). Zoom. México: Fondo de Cultura Económica.

BROWNE, A. (1993). El libro de los cerdos. México: Fondo de Cultura Económica.

(1995). El túnel. México: Fondo de Cultura Económica.

(1993). Cambios. México: Fondo de Cultura Económica.

(1999). Voces en el parque. México: Fondo de Cultura Económica.

DEPAOLA, T. (1999). Un pasito... y otro pasito. Colección libros de todo el mundo. Caracas: Ediciones Ekaré.

FOX, M. (1988). Guillermo Jorge Manuel José. Caracas: Ediciones Ekaré.

IPUANA, R. (2003). El burrito y la tuna: cuento Guajiro. Colección Narraciones indígenas. Caracas: Ediciones Ekaré. JUSAYÚ, M. \& Doppert, M. (1988). Ni era vaca ni era caballo. Colección Así vivimos. Caracas: Ediciones Ekaré.

KARUSA, M. (1981). La calle es libre. Colección Así vivimos. Caracas: Ediciones Ekaré.

KASZA, K. (2001). Choco encuentra una mamá. Bogotá: Editorial Norma.

LOBEL, A. (1987). El búho en casa. Caracas: Ediciones Ekaré.

NAZOA, A. (1997). El libro de los cochinitos. Maracay: Playco.

SKÁRMETA, A. \& Ruano, A. (2000). La composición. Colección Así vivimos. Caracas: Ediciones Ekaré.

VAN ALLSBURG, C. (1999). El expreso polar. Colección libros de todo el mundo. Caracas: Ediciones Ekaré.

WINTER, S. (1999). Yo puedo. Caracas: Ediciones Ekaré.

. (1999). Yo también. Caracas: Ediciones Ekaré.

YOUNG, E. (2001). Siete ratones ciegos. Caracas: Ediciones Ekaré.

Artículo Recibido el 31 de marzo de 2005 y aprobado el 12 de JUNio de 2005 